Daniela Gračan, Ph.D.

E-mail: danielag@fthm.hr University of Rijeka, Faculty of Tourism and Hospitality Management, Primorska 42, 51410 Opatija, Croatia

\title{
The Role Of Strategic Management In The Cruising Tourism Market Offer
}

\begin{abstract}
In the mid-70s of the last century, due to changes in the marketing strategy and repositioning of the entire sector on the market, the demand for cruise tourism experienced growth. One of the reasons for the relatively rapid development of the market of cruise tourism was conquering new segments of consumers and the development of new concepts of cruise that offers rest and relaxation with a variety of activities and entertainment on board.

Cruising has evolved into a major worldwide corporate business, and the dynamic changes in the reorganization of major cruise corporation went up with the high growth rates in demand on the world cruise market. The main objective of the reorganization of these large corporations is contained in adapting to the needs of tourists on cruise ships, trying to adjust the offer to growing demand - to its multi-functional and multi-disciplinary nature. Today, the dominating business and scientific-economic concept is a marketing approach in which the consumer-tourist is in the center of attention.
\end{abstract}

Key words: cruising tourism, strategic management, marketing approach, tourism destination.

\section{Introduction}

The assessment of the current position in a competitive market environment, as well as opportunities for improvement of the current position, are an indispensable prerequisite for the formation of the development strategy that will enable the achievement of sustainable competitive advantage. For an objective assessment of competitiveness, it is necessary to take into account the value of tourism resource, which has primary importance, especially when it comes to transit destinations, following with the functionality of the port system, capacities for accommodation of ships and passengers, and the infrastructure and organization of cruise destinations in general.

Destination Management implies determination of development objectives compatible with the existing strategic planning documents and laws and limits in 
the sustainability of development, defining mechanisms of action and management in accordance with its objectives, and continuously adjusting operational targets to development strategy.

The development of cruising, as an important subspecies of nautical tourism, has avoided the necessary strategic management at the macro level, which has brought it into the focus of research on sustainable development, which in some areas indicates the negative effects of cruising. This is due to the relatively small number of research papers focused on shaping strategic management on the macro-level which would help to resolve this problem, as well as with the still insufficiently developed scientific thoughts of cruising that would affect the change in practice. ${ }^{1}$ Tourists or cruise users are not yachters, as the case is with chartering. They are ordinary tourists, who love the sea and want to experience tourism in the classical sense, with visiting interesting destinations by using a luxury ship. Binds are found in the fact that their needs are met in a group of elite tourism.

The continued interest in cruises and the fact that $60 \%$ of passengers on board have already cruised, presents shipping companies with the need for constant development of this segment, and thus prompts them toward some kind of specialization. With deeper market segmentation, shipping companies establish market niches based on specific needs and interests (parents, singles, young), which directs them to such an offer that will meet the needs of tourists, such as hobbies, learning, listening to music, festivals, theater performances, exploring different cultures, cuisine.

\section{Characteristics of cruise tourism trends}

The demand for cruising has reached nearly twelve million trips, out of which about two-thirds are related to the North American market. The European market is the second largest with around four million trips, but with the highest growth rates. The leading European market is the market of the United Kingdom, followed by Germany, Italy, France and Spain. UNWTO estimates that by 2018, about 24 million passengers will be included in the cruise, representing an increase of 70 percent compared to 2008 and 54 per cent to $2010 .^{2}$ The number of passengers on cruise ships is estimated at approximately 22 million and, as compared to 2004, indicates an increase in demand of about 2.5 times. ${ }^{3}$ A similar trend is expected in the future, and estimations of the Passenger Shipping Association (PSA) in 2015 are ranging up to 23 million passengers on cruise voyages in the world. ${ }^{4}$

$1 \quad$ Luković, T.; Šerić, N.: Strateški razvoj i promjene legislative nautičkog turizma Hrvatske, Pomorstvo, y. 23, No. 2, Sveučilište u Rijeci, Rijeka, 2009., p. 157

2 Peručić, D., Doprinosi marketinga razvoju pomorskih krstarenja u drugoj polovici 20. stoljeća, Ekonomska misao i praksa, god. XV (2010.), No. 2, p. 162.

3 Cruise Ship Tourism (2015). Editor Ross K. Dowling, CAB International, p. 5.

4 Passenger Shipping Association: Discover Cruises - Annual cruise review, 2015. 
The cruise market shows constant changes in the demand trends - the long and expensive trips are rarer and there is a great interest for short cruises lasting just a few days and providing diverse entertainment and contents. Passengers are getting younger and better educated; there are more passengers with lower annual income and more passengers with small children. One of the characteristics of the market is also a high proportion of passengers who are for the first time on cruise. The North American market is dominant, so it seals the world market of sea cruises. The prevailing travels are those lasting from six to eight days, and the largest increase was recorded in the trips lasting from two to five days, while the long-term travels are only symbolically represented. In the competitive game, economies of scale (massiveness) have been gradually suppressing "the classics" (individuality).

Preferences of tourists result in offer of themed cruises that are now becoming more represented and more diversified on the market. Although plenty of time and money are basic prerequisites for long cruises or cruises around the world, the interest of passengers for such cruises is not negligible. There is a growing interest in cruises of adventurous nature, and a separate segment consists of incentives and conferences, which represents a novelty in the market and, owing to its advantages, attracts great interest among major cruise lines.

\section{Table 1. Market Overview of cruise tourism}

\begin{tabular}{|c|c|c|}
\hline Arrangements / Type & Explanation & Offer / market \\
\hline $\begin{array}{l}\text { Leisure, entertainment, } \\
\text { sightseeing, visiting ports } \\
\text { along the docking route }\end{array}$ & $\begin{array}{l}\text { markets around the } \\
\text { world }\end{array}$ & $\begin{array}{l}\text { different ships are built for } \\
\text { mass market of maritime } \\
\text { cruises }\end{array}$ \\
\hline $\begin{array}{l}\text { Special interest (navigation, } \\
\text { education and research) }\end{array}$ & $\begin{array}{l}\text { markets around the } \\
\text { world, highly } \\
\text { differentiated }\end{array}$ & $\begin{array}{l}\text { general purpose ships, } \\
\text { special crew, the degree } \\
\text { of monopoly through } \\
\text { differentiation }\end{array}$ \\
\hline $\begin{array}{l}\text { Long cruises, including } \\
\text { cruises around the world }\end{array}$ & $\begin{array}{l}\text { the common world } \\
\text { market }\end{array}$ & $\begin{array}{c}\text { large ships, rely on "tradition" } \\
\text { and luxury }\end{array}$ \\
\hline $\begin{array}{l}\text { Extended travel by ferry, } \\
\text { "Mini-cruise" }\end{array}$ & $\begin{array}{l}\text { mainly domestic } \\
\text { market or between } \\
\text { the two countries, } \\
\text { especially in the } \\
\text { western Europe }\end{array}$ & joint product with ferry services \\
\hline Short cruises & $\begin{array}{l}\text { world market, } \\
\text { differentiated } \\
\text { by location, the } \\
\text { dominance of the } \\
\text { Caribbean area }\end{array}$ & $\begin{array}{l}\text { the majority of large ships, } \\
\text { usually built specifically for the } \\
\text { mass market of maritime } \\
\text { cruises }\end{array}$ \\
\hline
\end{tabular}

Source: Adapted from Bull, O. A.: The Economics of Cruising: An application to the short ocean cruise market, The Journal of Tourism Studies, Vol. 7, No. 2, 1996., p. 29. 
Therefore, it is concluded, that the market is divided into: ${ }^{5}$

1. Entertaining cruises that can encompass all those cruises which for the fundamental objective have rest, leisure, entertainment, sightseeing and visiting ports along the way. Sailing the sea for pleasure is today a mass phenomenon, and the largest number of passengers make a choice precisely of this type of cruises. The ship no longer means only a way of transportation or a vessel transporting passengers but becomes an integral - an independent destination. By boat cruising across the seas of the world, interesting areas are visited and, however, the ship itself offers something interesting for each traveler. Today, entertainment boats are prevailing - pleasure for everyone, because the structure of the passengers is extremely diverse in all socio-demographic and economic characteristics - gender, age, preferences, travel motivations, income, marital status...

2. Cruises around the world: the characteristics of this segment of tourists is that most of them have already cruised around the world, they are choosing a cruise around the world each year, or at least every second or third year, they are by the majority elderly people and carry out the reservation well in advance to take advantage of early booking discounts. ${ }^{6}$

3. Theme cruises: with the growth of the maritime cruises market there is a need for getting travelers back by offering them a new product, and this can be achieved by offering new itineraries and a variety of destinations. Almost all shipping companies are increasingly offering theme cruises focused on market segments with common interests, such as music, sports, cooking, history, archeology (Disney theme cruises). ${ }^{7}$

4. Adventure Cruises are usually divided into three segments - the expedition / research cruises, sailing cruises and cruises by other specialized vessels. ${ }^{8}$ The first kind of expeditionary research cruises is generally related to the hard-to-reach areas, and the most popular itineraries are definitely the North and South Poles. ${ }^{9}$ The second group consists of cruises on board sailboats, with some cruise programs encouraging active participation of passengers and crews. Cruises on board other specialized ships are a separate segment of adventure cruises and their itineraries have emphasis on the pronounced educational element with mild adventure elements (so called Soft adventure).

5. Mini cruises or extended ferry cruises are also a form of sea cruises. Many ferries are converted into cruise ships in a way that the space for vehicles is replaced by passenger cabins.

Vojvodić, K.: Tržišne niše u krstarenjima morem, Naše more, 52(3-4), Rijeka, 2005. p.157 - 161

6 Marti, B. E.: Trends in world and extended-length cruising (1985-2002), Marine Policy, Vol. 28, No. 3, 2004., p. $199-211$.

7 Page K.: The future of cruise shipping, Tourism Management, Vol. 8, No. 2, 1987., str. 167.

8 Vladimir, N.: Seabourn Cruise Line: A Case Study in Achieving Quality, FIU Hospitality Review, Vol. 13, No. 1, 1995., p. 11.

9 Ritter, W.; Schafer, C.: Cruise-tourism: a chance of sustainability, Tourism Recreation Research, Vol. 23, No. 1, 1998., p. 66. 
6. Incentives and conferences are a special segment of the cruise. The reasons why the cruises product has become suitable for the development of this segment lies in the fact that this form is still considered a novelty and is the 'all-inclusive' type. ${ }^{10}$ Reservations can be made up to 18 months prior to departure and the entire ship may be rented and, as an outstanding advantage, all the delegates accommodated within close space. The nature of incentive cruises covers a wide range - from various conferences, various seminars or business meetings to free space without an established program. Renting the whole boat at the same time leaves the organizers the ability to change the itinerary, ship decoration and design, and warranty as well as a sense of privacy and exclusivity.

From the specific character of operations, it is clear that the specific management is being profiled that must meet all business problems. In striving to achieve competitiveness in the highly dynamic cruises market, tourist destinations in their development plans must take into account the characteristics of cruises trends, the most important of which are following: ${ }^{11}$

massiveness and the availability to widening economic strata;

increase in the size of ships - an increasing proportion of ships of up to $330 \mathrm{~m}$, with a capacity of over 3,000 passengers, with the volume of more than 100,000 BT; relatively short duration of the average tourist cruise package (less than 7 days); very defined and sophisticated package of services which includes 'all - inclusive' trip arrangements, tailored to relatively short stay in the destination (about 5 hours);

adaptation of port infrastructure for mega-ships and construction of passenger terminals.

The basic factor that affects the profile of management is the communication that takes place between the travel agency - cruising corporations - tourist / user. In business terms, organization of management is a mixture of tourism and maritime operations, which makes it specific in all terms. Communication which is organized, performed and encourages strategic management of cruise corporations, is functionally associated with the task of research of emitive markets. Based on information obtained through research (via publications, surveys, interviews, etc.) the management forms cruise tourism product.

\section{Cruising tourism strategic management}

Strategic management develops cruise products trying to popularize them even more, though, there is wrongly thinking that the cruise lines typically seeks to bring cruises to "everyone's pocket". Choosing the type of marketing strategy remains in the domain of strategic management and owners of cruise corporations. The fact remains

\footnotetext{
$10 \quad$ Worldwide Cruise Ship Activity, World Tourism Organization, 2003., Madrid, p. 48

11 Đurković, V.: op. cit., p. 33
} 
that the development of nearly all other types of tourism develops sinusoidal in terms of mass from not too massive to massive tourism. New development strategy should be based on a diversified, quality and market-custom tourist product and on the principles of respect for ecological balance and preservation of cultural heritage, which focuses its activities on the fulfillment of the expectations of tourists. ${ }^{12}$ It is estimated that future tourists will have the following characteristics: ${ }^{13}$

- they will express the yearning for new experiences and events;

- they will be aware of the supply quality;

- they will have developed sense of nature conservation and ecology;

- they will prefer the social, cultural and ecological unity, but with an emphasis on indigenous elements.

Strategic management of big cruise corporations and even small companies is generally conducted as the team. It is organized vertically, hierarchical, but because of the basic satisfaction of tourists / guests, horizontal organizational structure is important. Based on this structure, which has the main task to connect shipping organizational part with tourism, the main objective is successfully realized. In front of strategic management of cruise corporations, with very complex internal problems of organization, there are also ones set by the market, through which the success of business is verified. In this part, it is necessary to meet the particular function of continuous market research of supply and demand in world cruise, adjust the offer to wishes and needs of guests and create new products. In parallel, it is necessary to upgrade existing products, maintain a pricing policy and use it to strengthen position in the market. Strategic management of cruise corporations is very demanding and is aimed at a broad market of demand, which, already in its minimum considering of the possibilities of development, crosses national borders. Functionally, differences between cruise companies are very pronounced because each of them has its own specific policies and specific strategic management.

\section{The influence of cruising tourism on the destination}

The impact of cruise tourism on the destination of call is largely determined by the ratio of the destinations and the development of economic activity. The impact on the cruise destination is multidimensional and is usually monitored by impacts on society, economy and environment. ${ }^{14}$

12 Gračan, D.; Stipanović, C.: Značaj brodskih tura u razvojnoj strategiji Hrvatskog turizma, Zbornik radova Pravnog fakulteta u Splitu, god. 42., 2005., p. 206

13 Magaš, D.: Tourist destination in the globalisation process, Hotel 2000., Faculty of tourism and hospitality management, Opatija, 2000., p. 190

14 Studija održivog razvoja kruzing turizma u Hrvatskoj, op. cit., p. 65 
The social impact of the cruise destination primarily relates to the consequences that international cruise lines have on stationary tourists and the local population in the destination where such ships dock. This influence is viewed through the perception of tourists in the destination and the local population about the impact of the ship / cruisers and visitors from cruise ships on the attractiveness of temporary residence and living in the destination.

The impact of cruises on stationary tourism was estimated for the hotel guests segment in the coastal and island destinations visited by cruise ships on international cruise in Croatia. Research results sent a warning to all those destinations that aspire to significant growth of cruise tourism, which is that the flow of tourists and generally their activity should be systematically managed, the way in which tourism affects the local population together with economic and social benefits from tourism and cruise tourism should be systematically monitored and residents should be informed about them in a timely manner, in order to ensure that the tolerance of some negative impacts of tourism which are personally felt is balanced with the realization of the economic benefits that this activity brings to the entire community.

The perception of the economic benefits from cruise to the destination depends on the scale of cruise tourism in the destination with regard to the size of the destination. The income from the international cruise destination of berthing consists of the amount spent by passengers and crew who go ashore from the ship at the destination and the fees paid by the ship at port (port charges and fees and other revenues from the ship). Most benefits from international cruise are generated from this income. The rest of the benefits generated from the international cruise at destinations, include creation of new jobs related to the needs of the cruise, a general impetus to development as a result of revenue from cruise, destination promotion, etc.

The actual economic impact of international cruise on port destinations, regions and the country as a whole can be fully comprehended only on the basis of the inputoutput analysis. Such a comprehensive analysis is not available today, so the economic impact is monitored by total income from an international cruise, and the impact of cruise experience on re-visiting Croatia as a stationary guest is also analyzed. Based on the assessment of individual items of revenue from international cruise in Croatia in 2006, the approximate order of magnitude of the total direct revenue from the economic activity falls within the range of 29 to 32 million. In addition to income, there are also, of course, the costs associated with international cruise destination (local government, service providers, the wider community etc.).

If the economic impact of tourism is measured, it should be remembered that this is a much more demanding job than just calculating the level of tourist spending. The assessment of the economic impact of tourism based on tourist spending can be not only inaccurate, but often misleading. It is therefore necessary, before determining the method for measuring the economic impact of tourism, to look at different aspects of the economy under the influence of tourist consumption. There is a difference in determining the economic impact of tourist spending and tourism development. 
Calculating the economic impact of tourist spending is done by applying a multiplier analysis, while the estimation of economic impact of projected tourism development is performed using techniques such as the cost - benefit analysis, etc. ${ }^{15}$

Scheme 1. Positive and negative socio - cultural impacts of tourism

\begin{tabular}{|c|c|c|}
\hline \multirow{2}{*}{$\begin{array}{l}\text { The object of } \\
\text { socio - cultural } \\
\text { impact of } \\
\text { tourism }\end{array}$} & \multicolumn{2}{|c|}{ Socio - cultural effects of tourism } \\
\hline & Positive & Negative \\
\hline $\begin{array}{c}\text { Tourist - society } \\
\text { of mainly } \\
\text { outgoing } \\
\text { markets }\end{array}$ & $\begin{array}{l}\text { - development of „travel culture“ } \\
\text { - getting to know the culture and } \\
\text { history of other nations } \\
\text { - better understanding between } \\
\text { people from political countries, } \\
\text { with different cultural - } \\
\text { historical heritage } \\
\text { - increase of sociability among } \\
\text { people and reduction of social } \\
\text { tensions } \\
\text { - application of positive } \\
\text { experiences gained through } \\
\text { tourist movements in } \\
\text { permanent residence } \\
\text { - self-realization, release of } \\
\text { tension and pleasure ... }\end{array}$ & $\begin{array}{l}\text { application of negative } \\
\text { experiences obtained } \\
\text { on tourist movements in } \\
\text { permanent residence }\end{array}$ \\
\hline $\begin{array}{l}\text { Resident - a } \\
\text { society of } \\
\text { predominantly } \\
\text { receptive } \\
\text { countries }\end{array}$ & $\begin{array}{l}\text { - development of tourism culture } \\
\text { - exchange of cultural } \\
\text { information, ideas and beliefs } \\
\text { with other nations } \\
\text { - valorization of social activities } \\
\text { of a destination } \\
\text { - revival of old customs and } \\
\text { cultural events } \\
\text { - preservation and stimulation of } \\
\text { traditional crafts ... }\end{array}$ & $\begin{array}{l}\text { - demonstration effect (residents } \\
\text { imitate the behavior of } \\
\text { tourists) } \\
\text { - migration of workers from } \\
\text { rural to urban area } \\
\text { - changes in consumer habits } \\
\text { - loss of cultural identity } \\
\text { - fake imitation of ,authentic“ } \\
\text { atmosphere } \\
\text { - criminal growth } \\
\text { - moral erosion } \\
\text { - rising tension caused by } \\
\text { feelings of servility and others. } \\
\text { - the spread of infectious } \\
\text { diseases ... }\end{array}$ \\
\hline
\end{tabular}

Source: Križman Pavlović, D.: Upravljanje marketingom turističke destinacije, Mikrorad, Zagreb, 2008., p. 21

$\overline{15}$ Cooper i dr.: Tourism: principles and practice, Longman, Essex, 1998., p. 131 
Only with the identification and calculation of all income and expenses (direct ones, which are paid by providers and indirect, incurred by the wider community) and the evaluation of other benefits of the cruise, the overall effect of this kind of economic activity on destination could be assessed.

\section{Scheme 2. Structure of total revenues from cruise tourism}

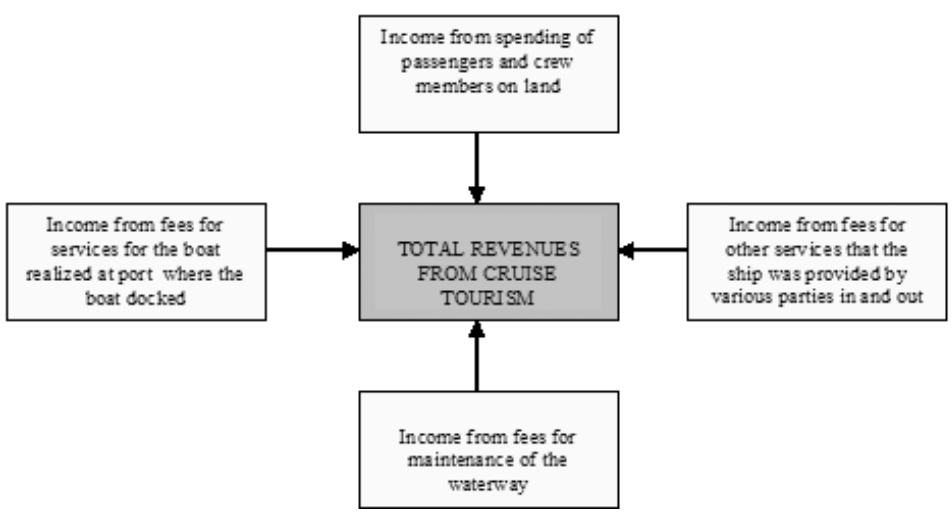

Source: Studija održivog razvoja kruzing turizma u Hrvatskoj, Institut za turizam, Zagreb, 2007., $p .72$

Income from spending of passengers and crew on land are generally the largest part of total revenues generated from cruise destinations.

In addition to passengers and crew members who go down from cruise ships and carry certain consumption in destinations, income from the cruise destinations are realized, as stated, according to several grounds. The most important one is the revenue collected by the port from handling such ships, and income from the use of the port and the revenue that is realized from providing a variety of other services for ship in the port (profit from shipping agents for services for shipping companies, revenue from the customs service, the revenue generated by other services for the vessel, such as garbage collection, water and food provision, etc.).

\section{Croatia in the market of cruise tourism}

Cruising has become in recent years an increasingly important segment of tourist demand in Croatia. The largest portion of the total traffic of tourists at cruise lines in Croatia is carried out in the port of Dubrovnik, and an ever more presence and turnover growth is being realized in the ports of Split and Zadar. 
The trends in the international cruise market opens up opportunities for significant progress for Croatia on this market. The expected above average growth in the world and Mediterranean cruise market, entry of new market segments (eg. youth, family), diversification of supply and constant search for new markets and new destinations for cruise products (eg. theme cruises, so-called. 'Cruise-and-stay' trips that combine the stay on board with a room in a vacation destination) represent an opportunity for a number of Croatian destinations in generating competitive offers aimed at cruise guests. In this context and in line with the vision, the intensification of promotional activities is one of the essential steps in creating the desired position for Croatia on the international cruise trips market. In this moment, it is possible to talk about the three-way cruise promotion in Croatia: promotion of Croatia as a cruise destination, promotion of certain Croatian ports as the starting ports and internal promotion focused on specific interest groups in Croatian tourist destinations.

Promotion of Croatia as a cruising destination aims at significant establishment of Croatian destinations in the growing international market of cruise trips. In doing so, Croatia wants to be presented as a destination whose diverse destinations can be very attractive for different types of cruise trips. Croatia or its individual ports can be further promoted as a starting port for cruises along the Adriatic and on to the Ionian and Aegean Sea. For certain carriers, this could be an interesting proposition, both from the perspective of lower costs in Croatian ports and the possibility for the ports of call and the organization of excursion itineraries to some new, still 'exotic' destinations: Croatia, Montenegro and Albania, and, furthermore, Greece and Turkey. Finally, the internal promotion aimed at the Croatian public in general and specifically to interest groups in certain destinations may affect the creation of a positive image of the cruise as well as the awareness of the role of networked destinations in creating the overall quality of cruise products.

Effective promotion of cruising in Croatia implies the existence of holders of promotional activities. In fact, it is certain that some ports and destinations which are interested in attracting cruisers will work on their own promotion, but there is no doubt that a common promotional message, not to mention a united financial instrument, can be much more effective in achieving the systematic promotion and gaining attention of the target audience. In this sense, it is important to establish a joint body that would be responsible for the joint promotion of Croatian cruising destinations. An example of such forms of association at the international level is the organization MedCruising which pools Mediterranean ports included in the cruise, aiming primarily at promoting the Mediterranean as a desirable destination for cruises. The underlying assumption of performing promotional activities is the existence of stakeholders and the establishment of a joint body whose function would be to promote Croatia as a cruising destination.

With the development of effective marketing strategies and their successful implementation on the market of maritime cruises, many shipping companies have successfully positioned themselves in different markets and within different segments of consumers, resulting in growing demand for maritime cruises. 
The package of services, which is a tourist destination product, basically consists of a service part, ie. the ship and passengers accommodation in the harbor, and the consumption of tourism resources. Since the business of tour operators is always oriented toward satisfying the consumers, when selecting the destinations, company will primarily take into account the appeal of destinations to potential tourists - the attraction of itinerary. If, however, from a set of destinations that belong to the same category according to importance, image and other characteristics which belong to the same competitive environment, it is necessary to make a choice, the competitive advantage of the port will come to the fore as an important criterion. This is confirmed by a series of researches on the factors affecting the competitiveness of the port. ${ }^{16}$ The tourist product of cruise destinations is the main attractive factor for the arrival of cruisers. The arrival of cruisers in destination means descent of a number of guests from cruise ships at the destination, who are willing to spend a certain amount of money for their needs. It is in the interest of destination to make the consumption higher, so the offer or at least part of the offer has to be adjusted to requirements of potential customers from cruisers. To make this possible, the first thing to be done is an analysis of demands of such guests at cruise destinations. The starting point consists of three important facts:

1. cruise visitors are very satisfied with the overall offer in Croatian tourist destinations as well as with most of its segments,

2. the average spending by visitors from cruisers on land in Croatia shows that there are considerable differences in the amount and structure and consumption among destinations,

3. the number of excursions offered to visitors of port destinations is not appropriate, since in some of them there are no excursions offered at all, while in others their number is within or below average.

Many authors who have tried to establish the basic market characteristics of the product, mainly agree that in order for the product to have success on the market it has to possess qualities such as attractiveness of the product to the consumer, competitive price, good quality characteristics with regard to the material and method of manufacture (functionality), distinctive and appealing design, availability for the final consumer on the market. ${ }^{17}$ There is plenty of room for improvement of the tourism product designed for cruising tourists, even in the most established local cruising destinations - and some of the guidelines for its improvement are:

- to improve the availability of tourist brochures for cruiser guests;

- to improve the circulation of vehicles and pedestrians in the destinations;

- to improve the look of the destination and its surrounding area as well as the tourist signalization

- to improve the offer of destinations in order to achieve higher average

$16 \quad$ Studija održivog razvoja kruzing turizma u Hrvatskoj, 2007., op. cit., p. 105.

17 Domijan-Arneri, I.; Lončar, M.: Ekonomske posljedice specijalizacije u morskom brodarstvu, Naše more 53(5-6), Rijeka, 2006. str. 192. 
spending by visitors from cruisers on land: the differences in the amount and structure of spending by visitors from cruisers in Croatian destinations suggest possible directions for the development of supply;

- to provide adequate prior information for passengers on board about destination, through various media; in this way, passengers may develop higher level of interest in visiting the destination, whereby additional spending in the destination may be stimulated.

A particular problem deals with excursions, where proper organization may determine the primary tourist attraction, and the destination may receive more visitors from cruisers than proposed by the carrying capacity of the destination, which also means higher revenue from the international cruising without compromising the sustainable development of destinations.

\section{Conclusion}

Cruising tourism in the world, as a tourism product, is still in the take-off phase and in the coming years we can expect growth in demand in high rates with effects that are hard to perceive. That is why the development of cruising in Croatia needs a radically different approach from the existing one. Good organization of the offer or even of the entire cruising system and, accordingly, an appropriate marketing and development planning of the infra and superstructure, particularly of ports, in addition to tourist destinations with their functional environment, can significantly contribute to better position of Croatia, in cooperation with shipping companies in the planning of cruising. It is possible to distinguish the dual orientation of the offer, which is based either on the entertainment and contents which are offered to passengers on board or on preferences for docking in ports together with cultural and historical sightseeing tours and enjoying the scenery. This offer is primarily a result of a variety of demands and the maturity of the main pillars of maritime cruises, which are in the market competition trying to meet all the requirements of particular segments for passengers on the cruises. Large companies seek to offer, at any price, something new and original that will be crucial for travelers to opt just for their ships and itineraries offered. In the tourist activity, great potential is seen for economic improvement of a considerable number of tourist destinations and for Croatia as a whole, but only provided proper organization and management of the development.

Cruising tourism is a new form of tourism with a high rate of growth. The number of cruise passengers has increased in the past twenty years by more than five times and high growth rates are expected in the coming period. Its attractiveness comes from the richness and differentiation of tourist facilities on board and from aspirations of tourists for traveling and exploring new destinations, cultures and customs. Cruising tourism intensifies active holiday of tourists interwoven with many experiences and changes. The dynamism and diversity of the supply and satisfaction of tourists condition their return visits and attraction of more and more numerous market segments. 


\section{Literature}

1. Bull, O. A.: The Economics of Cruising: An application to the short ocean cruise market, The Journal of Tourism Studies, Vol. 7, No. 2., The Department of Tourism, James Cook University of North Queesland, 1996.

2. Dibb, S.: Marketing, Mate, Zagreb, 1991.

3. Domijan-Arneri, I.; Lončar, M.: Ekonomske posljedice specijalizacije u morskom brodarstvu, Naše more 53 (5-6), Rijeka, 2006.

4. Cooper i dr.: Tourism: principles and practice, Longman, Essex, 1998.

5. Gračan, D.: Stipanović, C.: Značaj brodskih tura u razvojnoj strategiji Hrvatskog turizma, Zbornik radova Pravnog fakulteta u Splitu, god. 42., 2005.

6. Institut za turizam: Brodska kružna putovanja, Tomas 2006., Cavtat, 2006.

7. Križman Pavlović, D.: Upravljanje marketingom turističke destinacije, Mikrorad, Zagreb, 2008.

8. Luković, T.: Šerić, N.: Strateški razvoj i promjene legislative nautičkog turizma Hrvatske, Pomorstvo, god. 23, br. 2, Sveučilište u Rijeci, Rijeka, 2009.

9. Magaš, D.: Tourist destination in the globalisation process, Hotel 2000., Faculty of tourism and hospitality management, Opatija, 2000.

10. Marti, B. E.: Trends in world and extended-length cruising (1985- 2002), Marine Policy, Vol. 28, No. 3, 2004.

11. Page K.: The future of cruise shipping, Tourism Management, Vol. 8, No. 2, 1987.

12. Passenger Shipping Association: Discover Cruises - Annual cruise review, 2015.

13. Peručić, D: Doprinosi marketinga razvoju pomorskih krstarenja u drugoj polovici 20. stoljeća, Ekonomska misao i praksa, god. XV, br. 2; 2010.

14. Ross K. Dowling: Cruise Ship Tourism, Editor Ross K. Dowling, CAB International, 2015.

15. Studija održivog razvoja kruzing turizma u Hrvatskoj, Institut za turizam, Zagreb, 2007.

16. Vladimir, N.: Seabourn Cruise Line: A Case Study in Achieving Quality, FIU Hospitality Review, Vol. 13, No. 1, 1995.

17. Vojvodić, K.: Tržišne niše u krstarenjima morem, Naše more, 52(3-4), Rijeka, 2005. 
Danijela Gračan

\section{Uloga strateškog menadžmenta u tržišnoj ponudi kruzing turizma}

\section{Sažetak}

Sredinom 70-ih godina prošloga stoljeća zbog promjene marketinške strategije i repozicioniranja čitavoga sektora na tržištu, raste potražnja za kruzing turizmom. Jedan od razloga relativno brzom razvoju tržišta kruzing turizma, bilo je osvajanje novih segmenata potrošača i razvoj nove koncepcije krstarenja koja nudi odmor i relaksaciju uz mnoštvo sadržaja i zabave na brodu.

Kruzing se razvio u veliki svjetski korporativni biznis a dinamične promjene na planu reorganizacije velikih kruzing korporacija išle su ukorak s visokim stopama rasta potražnje na svjetskom kruzing tržištu. Osnovni cilj reorganizacije tih velikih korporacija sadržan je u prilagođavanju potrebama turista na kruzerima, pokušavajući ponudu prilagoditi sve hirovitijoj potražnji, to jest njezinoj multifunkcionalnosti i multidisciplinarnosti. Danas dominirajući poslovni i znanstveno-gospodarski koncept je marketinški pristup u kojemu je potrošač turist u središtu pozornosti.

Ključne riječi: kruzing turizam, strateški menadžment, marketinški pristup, turistička destinacija 